\title{
ARE THE HELMINTH COMMUNITIES FROM UNISEXUAL AND BISEXUAL LIZARDS DIFFERENT? EVIDENCE FROM GASTROINTESTINAL PARASITES OF DAREVSKIA SPP. IN TURKEY
}

\author{
Vicente RocA ${ }^{1,2}$, FÁtima Jorge ${ }^{2,3}$, Çetin IlgaZ ${ }^{4}$, Yusuf Kumlutaș ${ }^{4}$ \\ Salih Hakan Durmuș ${ }^{5}$ and Miguel A. Carretero ${ }^{2}$ \\ ${ }^{1}$ Departament de Zoologia, Facultat de Ciències Biològiques, Universitat de València \\ Dr. Moliner, 50, 46100 Burjassot, Spain; E-mail: vicente.roca@uv.es \\ ${ }^{2} \mathrm{CIBIO}$ Research Centre in Biodiversity and Genetic Resources, InBIO \\ Universidade do Porto, Campus Agrário de Vairão, Rua Padre Armando Quintas, 7. \\ 4485-661 Vairão, Vila do Conde, Portugal; E-mail: carretero@cibio.up.pt \\ ${ }^{3}$ Departamento de Biologia, Faculdade de Ciências da Universidade do Porto \\ R. Campo Alegre, s/n, 4169-007 Porto, Portugal; E-mail: fatima.esperanca@cibio.up.pt \\ ${ }^{4}$ Department of Biology, Faculty of Science, Dokuz Eylül University, Buca, İzmir, Turkey \\ E-mails: cetin.ilgaz@deu.edu.tr,yusuf.kumlutas@deu.edu.tr \\ ${ }^{5}$ Department of Biology, Faculty of Education, Dokuz Eylül University, Buca, Izmir, Turkey \\ E-mail: salih.durmus@deu.edu.tr
}

Specimens of three species of parthenogenetic lizards (Darevskia uzzelli, D. bendimahiensis, and D. sapphirina) from northeastern Turkey were examined for gastrointestinal parasites. Only one species, the nematode Spauligodon saxicolae (Pharyngodonidae), was found. The extremely low infection and diversity parameters, falling among the lowest within the Palaearctic saurians, support depauperate helminth communities for these parthenogenetic lacertid lizards. Our results suggest that parthenogenetic Darevskia follow a pattern of parasitism similar to other unisexual lizards (i.e. Aspidocelis). The low rates of infection and diversity may be explained by the decreasing opportunities for interchanging helminths rather than factors of susceptibility of unisexual hosts.

Key words: parasites, parthenogenetic lizards, Darevskia, Turkey.

\section{INTRODUCTION}

Caucasian rock lacertid lizards (Darevskia spp.) are small saurians from western Asia and south-eastern Europe. They are similar to the European rock lizards, and they include both bisexual and parthenogenetic species (ARNOLD et al. 2007, TARKhvishnili 2012). Among the unisexual forms, Darevskia uzzelli (Darevsky et Daniellyan, 1977), D. bendimahiensis (Schmidtler, Eiselt et Darevsky, 1994), and D. sapphirina (Schmidtler, Eiselt et Darevsky, 1994) are endemic to northeastern Turkey (SCHMIDTLER et al. 1994, BARAN \& ATATÜR 1998, BARAN et al. 2012). On the basis of genetic markers, all three parthenogenetic forms are believed to have originated by separate hybridization events between the bisexual Valentin's lizard, D. valentini (Boettger, 1892) (paternal parent), and Radde's lizard, D. raddei (Boettger, 1892) (maternal parent) (Fu 
et al. 2000, Murphy et al. 2000). D. bendimahiensis has been recorded from few localities from eastern Anatolia and it is listed as endangered because its extent of occurrence is less than $5000 \mathrm{~km}^{2}$ (KAsKa et al. 2009b). D. uzzelli and D. sapphirina are even more endangered species because they are rarest and narrower distributed species restricted only to small areas from eastern Turkey (AKARsu et al. 2009, KASKa et al. 2009a).

Several studies on both bisexual and unisexual Caucasian rock lizards have paid attention on morphology, taxonomy, ecology, phylogeny, reproductive traits or distribution of these saurians (Moritz et al. 1992, SCHMIDTLER et al. 1994, Fu et al. 1995, 1997, MacCullock et al. 2000, Murphy et al. 2000, Arnold et al. 2007, Danielyan et al. 2008, Tarkhvishnili 2012). Nevertheless much less attention has been paid to their parasites, and thus no helminthological data are known for most of the Darevskia species while known data for some of them are partial and scarce, focusing mainly on taxonomy and faunistics (Schad et al. 1960, Markov \& Bodganov 1962, Sharpilo 1962, 1976, SAYGI 1993).

One version of the Red Queen hypothesis (VAN VALEN 1973) suggests that selective pressure from parasites is strongest on the most common genotype in a population, and thus genetically identical clonal lineages with low genetic variability are expected to be more vulnerable to parasitism over time than genetically diverse sexual lineages. Sexual reproduction is maintained in populations because of the need to continually create genotypes that confer resistance against parasites (Hamilton et al. 1990, Ladle 1992). Among reptiles, some studies on ecto- and endoparasites have rendered conflicting results regarding this hypothesis. MoriTz et al. (1991) reported that parthenogenetic individuals of the Heteronotia binoei species complex (Australian geckos) were much more prone to infection by haematophagous mites than were their sexual relatives. Contrarily, Hanley et al. (1995) reported lower mite infections in parthenogenetic Lepidodactylus (Pacific Island geckos) compared with their sexual ancestors; and Menezes et al. (2004) pointed out the low infection rates by helminths of Ameivula nativo contrasting with the high values exhibited by the closely related bisexual congener $A$. littoralis in southeastern Brazil.

Most helminthological data on parthenogenetic lizards are known from teiid species, namely the whiptail lizards of the New World genus Aspidocelis (former Cnemidophorus) from North and Central America. Within the 41 species of Aspidocelis, numerous unisexual taxa are common inhabitants of the desert areas of the southwestern United States and adjacent Mexico (McAllister 1992). McAllister $(1990 a, b, c)$, McAllister et al. (1986, 1991a,b,c) studies, show poor helminth communities on several species of these parthenogenetic lizards and evidence that, the species of Aspidocelis usually share parasites, regardless of geographic location or even ancestry (McAlLister 1992). 
Table 1. Collecting localities of the lizard hosts.

\begin{tabular}{lccccl}
\hline Species & Site & Latitude & Longitude & Altitude $(\mathrm{m})$ & Habitat \\
\hline $\begin{array}{l}\text { D. uzzelli } \\
\text { D. uzzelli }\end{array}$ & Ağrasan & 39.936667 & 42.303667 & 1812 & $\begin{array}{l}\text { stepic vegetation with } \\
\text { rock cliffs }\end{array}$ \\
$\begin{array}{l}\text { D. bendi- } \\
\text { mahiensis }\end{array}$ & Muradiye & 39.723639 & 43.002821 & 1638 & $\begin{array}{l}\text { stepic vegetation with } \\
\text { rock cliffs }\end{array}$ \\
$\begin{array}{l}\text { D. sap- } \\
\text { phirina }\end{array}$ & $\begin{array}{l}35 \mathrm{~km} \\
\text { NW Erciş }\end{array}$ & 39.188099 & 43.001953 & 1793 & $\begin{array}{l}\text { stepic vegetation and } \\
\text { river bank } \\
\text { stepic vegetation and } \\
\text { isolated rocks }\end{array}$ \\
\hline
\end{tabular}

Similar findings have been reported for the parthenogens among the 10 species of Ameivula (i.e. Menezes et al. 2004), another teiid genus from South America, ecologically similar to Aspidoscelis (Harvey et al. 2012).

Finally, from a demographic point of view, parthenogenetic lizards and particularly Darevskia tend to attain higher densities than their bisexual relatives (Galoyan 2013). This, together with the low aggressiveness of parthenogenetic females allowing smaller home ranges (GaLOYAN 2013), might enhance parasite transmission.

In accordance with the findings above mentioned, we here predict low or moderate gastrointestinal parasite infection in parthenogenetic Darevskia spp. Thus, here we analyze the helminth communities of three parthenogenetic forms inhabiting saxicolous restricted habitats from northeastern Anatolia.

\section{MATERIAL AND METHODS}

Due to the capture restrictions for these endangered species escaping extremely restricted ranges or even single localities, only 20 specimens of $D$. uzzelli were collected from two localities, five specimens of $D$. bendimahiensis, and two specimens of $D$. sapphirina from single localities, respectively, all of them in Northeast Anatolia and separated by no more than $100 \mathrm{~km}$ (Table 1). Climate of the region is characteristic of the Anatolian Plateau with strong continental influence contrasting between cold, snowy winters $\left(-30^{\circ} \mathrm{C}\right)$ and dry, hot summers $\left(>30^{\circ} \mathrm{C}\right.$ ) and with total annual precipitation averaging $400 \mathrm{~mm}$ (SENsor et al. 2008).

Lizards were collected by hand, euthanized and dissected. While invasive, this method still ensures a better detection and quantification of intestinal parasites with a few specimens (Jorge et al. 2013). The gastrointestinal tracts were sent to the Laboratory of Parasitology of the University of Valencia for parasitological analysis. Helminths were processed in accordance with the usual techniques in parasitology (Hornero 1991). We follow Bush et al. (1997) in the use of descriptive ecological terms. Nematodes, voucher specimens are deposited in collection of Department of Zoology, Faculty of Biological Sciences, University of Valencia (Spain). Other data obtained from the searched hosts (taxonomy, thermoregulation, feeding habits, phylogeny, ecology), related with the geographical characteristics of the searched area are being object of other complex studies, according to DAMA protocol (Brooks et al. 2014). 
Table 2. Comparative values of helminth infection and diversity among some Palaearctic lacertid lizards.

\begin{tabular}{lccccc}
\hline Host species & $\begin{array}{c}\text { Helminth } \\
\text { species } \\
\text { found }\end{array}$ & $\begin{array}{c}\text { Global } \\
\text { preva- } \\
\text { lence }\end{array}$ & $\begin{array}{c}\text { Mean in- } \\
\text { tensity of } \\
\text { infection }\end{array}$ & $\begin{array}{c}\text { Mean abun- } \\
\text { dance of } \\
\text { infection }\end{array}$ & $\begin{array}{c}\text { Brillouin's } \\
\text { index of } \\
\text { diversity }\end{array}$ \\
\hline $\begin{array}{l}\text { Darevskia uzzelli } \\
(\mathrm{n}=20)\end{array}$ & 1 & $10 \%$ & $1 \pm 1(1-1)$ & $0.1 \pm 0.3(0-1)$ & 0 \\
$\begin{array}{l}\text { Darevskia bendimahiensis } \\
(\mathrm{n}=5)\end{array}$ & 1 & $20 \%$ & - & - & 0 \\
$\begin{array}{l}\text { Zootoca vivipara } \\
(\mathrm{n}=129)\end{array}$ & 2 & $39.4 \%$ & $\begin{array}{c}2.4 \pm 2 \\
(1-10)\end{array}$ & $0.9 \pm 1(0-10)$ & $0.002 \pm 0.02$ \\
$\begin{array}{l}\text { Podarcis bocagei } \\
(\mathrm{n}=249)\end{array}$ & 5 & $13.7 \%$ & $\begin{array}{c}3.4 \pm 4.1 \\
(1-27)\end{array}$ & $\begin{array}{c}0.2 \pm 1.3 \\
(0-27)\end{array}$ \\
$\begin{array}{l}\text { Podarcis carbonelli } \\
(\mathrm{n}=257)\end{array}$ & 4 & $4 \%$ & $\begin{array}{c}4.2 \pm 5.3 \\
(1-32)\end{array}$ & $\begin{array}{c}0.1 \pm 1.2 \\
(0-32)\end{array}$ & $0.001 \pm 0.02$ \\
\hline
\end{tabular}

\section{RESULTS}

Only one species of helminth, Spauligodon saxicolae (2 males and 2 females), was found in D. uzzelli and D. bendimahiensis. No parasites were found in D. sapphirina. The low number of helminths found and the poor conditions of conservation made impossible the specific identification of the parasites based in morphological characters. Prevalence of infection was $10 \%$ in $D$. uzzelli, 20\% in D. bendimahiensis. Only one individual of D. bendimahiensis was infected. Mean intensity and mean abundance of infection in $D$. uzzelli were $1 \pm 1(1-1)$ and $0.1 \pm 0.3(0-1)$, respectively. Brillouin's diversity index was 0 in all the three hosts (Table 2).

\section{DISCUSSION}

Morphological species identification was compromised by the specimens conservation state. However, genetic analysis retrieved the specimens as closely related to Spauligodon saxicolae Sharpilo, 1961, as occurs with several similar morphotypes found in other Darevskia spp. from Armenia (Jonge et al. 2014).

Obviously, and considering the low number of examined hosts, we can only provide a preliminary description of the composition and structure of their helminth communities. Nevertheless these results are already extremely valuable because of the low probability to analyse more specimens of these endangered hosts in the next future. 
The very low values of parasite infection and diversity cannot be attributed to sample size and suggest very poor helminth communities for these parthenogenetic host species. The Darevskia spp. analysed show the lowest diverse helminth communities reported to date within the Palaearctic lacertid lizards. Only Podarcis bocagei and P. carbonelli from North West of the Iberian Peninsula (GALdón et al. 2006), and Zootoca vivipara from Pyrenees (north of Iberian Peninsula) (SANCHIS et al. 2000) harboured equivalent impoverished helminth communities (Table 2). Is this the typical pattern in unisexual lizards? In this regard little is known on the parasites of other parthenogenetic lizards. Most data available come from Aspidocelis and Ameivula whiptail lizards (Teiidae). Studies of McAllister (1990a,b,c, 1992), McAllister et al. (1986, 1991a,b,c) and Menezes et al. (2004) provide descriptions on the parasite infection of this group characterizing their helminth communities as follows.

Aspidocelis spp. harbour poor helminth communities, in many cases most lizards of a population contained only one helminth species (McAlLister et al. 1991b). This agrees with our finding of a single species of the nematode Spauligodon saxicolae. Moreover, the infection and diversity values of the study parthenogenetic Darevskia spp. were poorer than those found in lizards which helminth communities have been considered as "extremely poor infracommunities" (GALDón et al. 2006) as the saurians mentioned above.

Usually parthenogenetic Aspidocelis spp. tend to be parasitized by the same helminths found in their parental species. For all the three Darevskia species studied, D. valentini is the paternal parent and D. raddei is the maternal parent (see Introduction). In $D$. valentini, four helminth species were found (Roca et al., unpubl. data) Spauligodon saxicolae being one of them. In D. raddei, only one species also belonging to Spauligodon saxicolae was recorded (Roca et al. unpubl. data).

Parthenogenetic lizards usually share parasites with parthenogenetic and bisexual congeners, regardless of geographic location or even ancestry. Spauligodon spp. (sometimes named as Skrjabinodon, see Jorge et al. 2014) has been recorded in many saurian hosts in many geographical regions. Namely, they have been found in lacertids as Podarcis spp., Algyroides marchi or Gallotia galloti (Roca \& Hornero 1994, Lafuente \& Roca 1995, Roca et al. 2005), and geckos as Tarentola mauritanica (Roca 1985a), in many areas of the Palaearctic and Macaronesia (see Roca 1985b, Hornero 1991, Martin 2005). Consequently, it seems that unisexual Darevskia spp. would share parasites with many other lacertid lizards.

Pharyngodonidae nematodes represent a substantial part of these depauperate helminth communities. This is also a typical pattern in Palaearctic lacertid lizards (see Hornero 1991, MarTin 2005, Roca 1985b). In the present case the nematode Spauligodon saxicolae (Pharyngodonidae) encompases the complete helminth communities present in all the three unisexual Darevskia hosts. 
Thus, the pattern observed in parthenogenetic Darevskia spp. appears very similar to that in Aspidocelis spp. These very poor helminth communities could be explained by the decreasing of opportunities for interchanging helminths of direct life cycles, since there are neither male-female (reproductive) nor male-male contacts (territorial fights). Apparently, this effect takes precedence over the high lizard densities (Galoyan 2013) in modelling the helminth communities of parthenogenetic Darevskia spp. Remarkably MENEZEs et al. (2004) suggest that males of Ameivula nativo from Brazil would be more susceptible than females to infection by some nematodes. The fact that this host was also all-female, could also be associated with its relatively low infection rates.

The small body size of the host, and a low number of interactions with other reptile and amphibian species, have been cited as cause of very low diversity of helminths in the case of Zootoca vivipara (SANCHIs et al. 2000). Sandy areas, as zones where recruitment of parasites by lizard hosts is low (eggs being highly susceptible to desiccation), have been also cited as cause for low helminth community diversity for $P$. bocagei and P. carbonelli (GALdón et al. 2006). Nevertheless, infection rates were not significantly influenced either by host body size or by environmental factors in the case of the parthenogenetic whiptail lizard Ameivula nativo (Menezes et al. 2004).

Although Moritz et al. (1991) assume that differences in parasitism are attributable to differences in susceptibility between the sexual and the asexual lizards, Clayton et al. (1992) pointed out that parasite load alone does not accurately predict host susceptibility. HANLEY et al. (1995) argue that the Red Queen model predict shifts in host susceptibility to parasites within a population, but adds that other factors are important in determining patterns of parasitism such as transmission rates (ANDERSON \& MAY 1982) or parasite virulence. The high densities attained by parthenogenetic lizards including Darveskia spp. (Galoyan 2013 pers. obs.) should have increased infection opportunities but this was not the case here. Nevertheless, further studies with more populations and with other parthenogenetic forms of Darevskia are needed to untangle the factors modelling helminth parasitation.

Acknowledgements - FJ was funded through a doctoral grant (SFRH/BD/77332/2011) under the Programa Operacional Potencial Humano - Quadro de Referência Estratégico Nacional funds from the European Social Fund and Portuguese Ministério da Educação e Ciência. Field work was partially funded by the projects "Preserving Armenian biodiversity: Joint Portuguese-Armenian program for training in modern conservation biology" of Gulbenkian Fundation (Portugal) and by PTDC/BIA-BEC/101256/2008 of Fundação para a Ciência e a Tecnologia, FCT (Portugal) supported by FEDER through the COMPETE 
program. Collecting permits (no. B.30.2.DEU.O.A8.00.00/54) were issued by Turkish Environmental Authority to the project 2009.KB.FEN.003 by Fauna and Flora Research and Application Center, Dokuz Eylul University.

\section{REFERENCES}

Anderson, R. M. \& May, R. M. (1982) Coevolution of hosts and parasites. Parasitology 85: 411-426. doi: 10.1017/S0031182000055360

Akarsu, F., Tuniyev, B., Anajeva, N., Agasyan, N., Orlov, N. \& Tuniyev, S. (2009) Darevskia uzzelli. In: IUCN 2013. IUCN Red List of Threatened Species. Version 2013.1. Retrieved 2009 from www.iucnredlist.org

Arnold, E. N., Arribas, O. \& Carranza, S. (2007) Systematics of the Palaearctic and Oriental lizard tribe Lacertini (Squamata: Lacertidae: Lacertinae), with description of eight new genera. Zootaxa 1430: 1-86.

Baran, I. \& Atatür, M. K. (1998) Turkish Herpetofauna (Amphibians and Reptiles). Republic of Turkey, Ministry of Environment, Ankara, 214 pp.

Baran, İ., Ilgaz, Ç., Avci, A., Kumlutaş, Y. \& Olgun, K. (2013) Türkiye Amfibi ve Sürüngenleri. TÜBİTAK Popüler Bilim Kitapları. TÜBİTAK, Ankara, 204 pp.

Brooks, D. R., Hoberg, E. P., Boeger, W. A., Gardner, S. L., Galbreath, K. E., Herczeg, D., Mejía-Madrid, H. H., Rácz, S. E. \& Dursahinhan, A. T. (2014) Finding them before they find us: Informatics, parasites, and environments in accelerating climate change. Comparative Parasitology 81: 155-164. doi: 10.1654/4724b.1

Bush, A. O., Lafferty, K. D., Loft, J. M. \& Shostak, A. W. (1997) Parasitology meets ecology on its own terms: Margolis et al. revisited. Journal of Parasitology 83: 575-583. doi: $10.2307 / 3284227$

Clayton, D. H., Pruett-Jones, S. G. \& Lande, R. (1992) Reappraisal of the interspecific prediction of parasite-mediated sexual selection: Opportunity knocks. Journal of Theoretical Biology 157: 95-108. doi: 10.1016/S0022-5193(05)80759-3

Danielyan, F., Arakelyan, M. \& Stepanyan, I. (2008) Hybrids of Darevskia valentini, D. armeniaca and D. unisexualis from a sympatric population in Armenia. AmphibiaReptilia 29: 487-504. doi: 10.1163/156853808786230424

Fu, J., Murphy, R. W. \& Darevsky, I. S. (1997) Towards the phylogeny of Caucasian rock lizards: Implications from mitochondrial DNA gene sequences (Reptilia: Lacertidae). Zoological Journal of the Linnean Society 121: 463-477. doi: 10.1111/j.1096-3642.1997. tb01283.x

Fu, J., Murphy, R. W. \& Darewsky, I. S. (2000) Divergence of the cytochrome b gene in the Lacerta raddei complex and its parthenogenetic daughter species: evidence for recent multiple origins. Copeia 2000(2): 432-440. doi: 10.1643/0045-8511(2000)000[0432:DOT CBG]2.0.CO;2

Fu, J., Darevsky, I. S., MacCullock, R. D., Kupriyanova, L. A., Roytberg, E. S., Sokolova, T. \& Murphy, R. W. (1995) Genetic and morphological differentiation among Caucasian lizards of the Lacerta caucasica complex. Russian Journal of Herpetology 2: 36-43.

Galdón, M. A., Roca, V., Barbosa, D. \& Carretero, M. A. (2006) Intestinal helminth communities of Podarcis bocagei and Podarcis carbonelli (Sauria: Lacertidae) in NW Portugal. Helminthologia 43(1): 37-41. doi: 10.2478/s11687-006-0008-y

Galoyan, E. A. (2013) Joint space use in a parthenogenetic Armenian Rock Lizard (Darevskia armeniaca) suggests weak competition among monoclonal females. Journal of Herpetology 47: 97-104. doi: 10.1670/11-242 
Hamilton, W. D., Axelrod, R. \& Tanese, R. (1990) Sexual reproduction as an adaptation to parasites (A review). Proceedings of the National Academy of Sciences, U.S.A. 87: 35663573. doi: 10.1073/pnas.87.9.3566

Hanley, K. A., Fisher, R. N. \& Case, T. J. (1995) Lower mite infestations in an asexual gecko compared with its sexual ancestors. Evolution 49(3): 418-426. doi: 10.2307/2410266

Harvey, M. B., Ugueto, G. N. \& Gutberlet, R. L. Jr. (2012) Review of Teiid morphology with a revised taxonomy and phylogeny of the Teiidae (Lepidosauria: Squamata). Zootaxa 3459: 1-156.

Hornero, M. J. (1991) Helmintofauna de los lacértidos endémicos de las Islas Baleares (Mediterráneo occidental). PhD Thesis, University of Valencia, Valencia, $277 \mathrm{pp}$.

Jorge, F., Carretero, M. A., Roca, V., Poulin, R. \& Perera, A. (2013) What you get is what they have? Detectability of intestinal parasites in reptiles using faeces. Parasitology Research 112: 4001-4007. doi: 10.1007/s00436-013-3588-8

Jorge, F., Perera, A., Roca, V., Carretero, M. A., Harris, D. J. \& Poulin, R. (2014) Evolution of alternative male morphotypes in oxyurid nematodes: a case of convergence? Journal of Evolutionary Biology 27: 1631-1643. doi: 10.1111/jeb.12430

Kaska, Y., Kumlutaș, Y., Avci, A., Üzüm, N., Yeniyurt, C. \& Akarsu, F. (2009a) Darevskia sapphirina. In: IUCN 2013. IUCN Red List of Threatened Species. Version 2013.1. Retrieved 2009 from www.iucnredlist.org

Kaska, Y., Kumlutaș, Y., Kaya, U., Avci, A., Üzüm, N., Yeniyurt, C. \& Akarsu, F. (2009b) Darevskia bendimahiensis. In: IUCN 2013. IUCN Red List of Threatened Species. Version 2013.1. Retrieved 2009 from www.iucnredlist.org

Ladle, R. J. (1992) Parasites and sex: catching the Red Queen. Trends in Ecology and Evolution 7(12): 405-408. doi: 10.1016/0169-5347(92)90021-3

Lafuente, M. \& Roca, V. (1995) Description of Skrjabinodon alcaraziensis sp. n. (Nematoda: Pharyngodonidae), a parasite of Algyroides marchi (Sauria: Lacertidae). Folia Parasitologica 42: 130-134.

MacCullock, R. D., Fu, J., Darevsky, I. S. \& Murphy, R. W. (2000) Genetic evidence for species status of some Caucasian rock lizards in the Lacerta saxicola group. AmphibiaReptilia 21: 169-176. doi: 10.1163/156853800507354

Markov, G. S. \& Bodganov, O. P. (1962) New nematodes for the fauna of the USSR. Izvestia Akademija Nauoba. Turkmenista SSR 1: 73-77.

Martin, J. E. (2005) Helmintofauna de los lacértidos endémicos de las Islas Canarias: relaciones parásito-hospedador. PhD Thesis, University of Valencia, Valencia, $162 \mathrm{pp}$.

McAllister, C. T. (1990a) Helminth parasites of unisexual and bisexual whiptail lizards (Teiidae) in North America. I. The Colorado Checkered Whiptail (Cnemidophorus tesselatus). Journal of Wildlife Diseases 26: 139-142. doi: 10.7589/0090-3558-26.1.139

McAllister, C. T. (1990b) Helminth parasites of unisexual and bisexual whiptail lizards (Teiidae) in North America. III. The Chihuahuan Spotted Whiptail (Cnemidophorus exanguis). Journal of Wildlife Diseases 26: 544-546. doi: 10.7589/0090-3558-26.4.544

McAllister, C. T. (1990c) Helminth parasites of unisexual and bisexual whiptail lizards (Teiidae) in North America. IV. The Texas Spotted Whiptail (Cnemidophorus gularis). The Texas Journal of Science 42: 381-388.

McAllister, C. T. (1992) Helminth parasites of unisexual and bisexual whiptail lizards (Teiidae) in North America. VIII. The Gila Spotted Whiptail (Cnemidophorus flagellicaudus), Sonoran Spotted Whiptail (Cnemidophorus sonorae), and Plateau Striped Whiptail (Cnemidophorus velox). The Texas Journal of Science 44: 233-239. 
McAllister, C. T., Cordes, J. E., Conn, D. B., Singleton, J. \& Walker, J. M. (1991c) Helminth parasites of unisexual and bisexual whiptail lizards (Teiidae) in North America. V. Mesocestoides sp. Tetrathyridia (Cestoda: Cyclophyllidea) from four species of Cnemidophorus. Journal of Wildlife Diseases 27: 494-497. doi: 10.7589/0090-355827.3.494

McAllister, C. T., Cordes, J. E. \& Walker, J. M. (1991a) Helminth parasites of unisexual and bisexual whiptail lizards (Teiidae) in North America. VI. The Gray-Checkered whiptail (Cnemidophorus dixoni). The Texas Journal of Science 43: 309-314.

McAllister, C. T., Trauth, S. E. \& Conn, D. B. (1991b) Helminth parasites of unisexual and bisexual whiptail lizards (Teiidae) in North America. VII. The Six-Lined Racerunner, Cnemidophorus sexlineatus. The Texas Journal of Science 43: 391-397.

McAllister, C. T., Trauth, S. E. \& Ubelaker, J. E. (1986) Nematode parasites of the parthenogenetic Whiptail lizard, Cnemidophorus laredoensis (Sauria: Teiidae) from South Texas. Proceedings of the Helminthological Society of Washington 53: 138-139.

Menezes, V. A., Vrcibradic, D., Vicente, J. J., Dutra, G. F. \& Rocha, C. F. D. (2004) Helminths infecting the parthenogenetic whiptail lizard Cnemidophorus nativo in a resting habitat of Bahia State, Brasil. Journal of Helminthology 78: 323-328. doi: http:// dx.doi.org/10.1079/JOH2004247

Moritz, C., McCallum, H., Donnellan, S. \& Roberts, J. D. (1991) Parasite loads in parthenogenetic and sexual lizards (Heteronotia binoei). Support for the Red Queen hypothesis. Proceedings of the Royal Society B, Biological Sciences 244: 145-149. doi: 10.1098/rspb.1991.0063

Moritz, C., Uzell, T., Spolsky, C., Hotz, H., Darevsky, I. S., Kupriyanova, L. A. \& DanielYAN, F. D. (1992) The material (sic maternal) ancestry and approximate age of parthenogenetic species of Caucasian rock lizards (Lacerta: Lacertidae). Genetica 87: 53-62. doi: 10.1007/BF00128773

Murphy, R. W., Fu, J., MacCullock, R. D., Darevsky, I. S. \& Kupriyanova, L. A. (2000) A fine line between sex and unisexuality: the phylogenetic constraints on parthenogenesis in lacertid lizards. Zoological Journal of the Linnean Society 130: 527-549. doi: 10.1111/j.1096-3642.2000.tb02200.x

RocA, V. (1985a) Skrjabinodon mascomai n. sp. (Nematoda: Pharyngodonidae), parasite of Tarentola mauritanica (Linnaeus, 1758) Gray, 1845 (Reptilia: Geckonidae) in Valencia (Spain). Rivista di Parassitologia 2: 27-31.

Roca, V. (1985b) Contribución al conocimiento de la helmintofauna de los lacértidos y geckónidos del piso termomediterráneo del levante ibérico. PhD Thesis, University of Valencia, Valencia, 486 pp.

Roca, V., Carretero, M. A., Llorente, G. A., Montori, A. \& Martin, J. E. (2005) Helminth communities of two lizard populations (Lacertidae) from Canary Islands (Spain): Host-diet parasite relationships. Amphibia-Reptilia 26: 535-542. doi: 10.1163/ 156853805774806160

Roca, V. \& Hornero, M. J. (1994) Helminth infracommunities of Podarcis pityusensis and Podarcis lilfordi (Sauria: Lacertidae) from the Balearic Islands (western Mediterranean basin). Canadian Journal of Zoology 72: 658-664. doi: 10.1139/z94-089

Sanchis, V., Roig, J. M., Carretero, M. A., Roca, V. \& Llorente, G. A. (2000) Host-parasite relationships of Zootoca vivipara (Sauria: Lacertidae) in the Pyrenees (North Spain). Folia Parasitologica 47: 118-122. doi: 10.14411/fp.2000.024

SAYGI, G. (1993) The genus Spauligodon (Nematoda: Oxyuroidea) in Lacerta parva collected in Sivas, Turkey. Türkiye Parazitoloji Dergisi 17: 40-45.

Sensoy, S., Demircan, M., Ulupinar, U. \& Balta, İ. (2008) Türkiye İklimi. Retrieved 2008 from http://www.dmi.gov.tr/iklim/iklim.aspx 
Schad, G. A., Kuntz, R. E. \& Wells, W. H. (1960) Nematode parasites from Turkish Vertebrates. An annotated list. Canadian Journal of Zoology 38: 949-962. doi: 10.1139/z60-101

Schmidtler, J. F., Eiselt, J. \& DARevsky, I. S. (1994) Untersuchungen an Feldeidechsen (Lacerta saxicola-Gruppe) in der östlichen Türkei: 3. Zwei neue parthenogenetische Arten. Salamandra 30(1): 55-70.

Sharpilo, V. P. (1962) New nematode Spauligodon saxicolae nov. sp. parasite of the scaly lizard, Lacerta saxicola. Trudy Ukrainskogo Respublikanskogo Nauchnogo Obshchestva Parazitologov 1: 241-244.

SHarpILO, V. P. (1976) Parasitic worms of the reptilian fauna of the USSR. Systematics, chorology, biology. Naukoba Dumka, Moskba, 287 pp.

TARkhvishnili, D. (2012) Evolutionary history, habitats, diversification, and speciation in Caucasian rock lizards. Pp. 79-120 In: Jenkins, O. P. (ed.): Advances in Zoology Research. Volume 2. Science Publishers, Hauppauge (NY).

VAn Valen, L. (1973) A new evolutionary law. Evolutionary Theory 1: 1-30.

Revised version received September 14, 2014, accepted January 20, 2015, published August 14, 2015 